\title{
New high yielding and disease tolerant wheat (Triticum aestivum L) variety NIFA AMAN-2017 for irrigated areas of Khyber Pakhtunkhwa
}

\author{
Fazle Subhan ${ }^{1}$, Muhammad Irfaq Khan ${ }^{1}$ and Syed Tariq Shah ${ }^{1 *}$ \\ 1. Nuclear Institute for Food \& Agriculture (NIFA), Peshawar, Khyber Pakhtunkhwa, Pakistan \\ *Corresponding author's email: stariq81@yahoo.com \\ Citation \\ Fazle Subhan, Muhammad Irfaq Khan and Syed Tariq Shah. New high yielding and disease tolerant wheat (Triticum \\ aestivum L) variety NIFA AMAN-2017 for irrigated areas of Khyber Pakhtunkhwa. Pure and Applied Biology. Vol. \\ 11, Issue 2, pp527-535. http://dx.doi.org/10.19045/bspab.2022.110052
}

Received: 27/06/2021

Revised: 04/08/2021

Accepted: 25/08/2021

Online First: 26/08/2021

\section{Abstract}

Varietal development, release and quality seed production of new high yielding and disease resistant wheat varieties is a continuous effort and a pre-requisite for sustainable wheat production. NIFA-AMAN 2017 as a new improved variety was developed at Nuclear Institute for Food and Agriculture, Peshawar, Pakistan. From $4{ }^{\text {th }}$ Stem Rust Screening Nursery ( $4^{\text {th }}$ SRSN) the genotype was selected and material received from CIMMYT in 2009-10. Based on disease tolerance and higher grain yield, the genotype (SRN-09111) was selected from the nursery sown during 200910. Similarly, in preliminary and advanced yield trials conducted at NIFA during 2010-11 and 2011-12, the genotype was evaluated. The SRN-09111 was also evaluated in microplot trial at 07 different sites of the province during 2012-13, genotype showed outstanding yield performance among the other genotypes. The genotype out yielded $\left(5647 \& 4351 \mathrm{~kg} \mathrm{ha}^{-1}\right)$ in $1^{\text {st }}$ year mandatory evaluation of National Uniform Wheat Yield Trials (NUWYT) during 2013-14 and Ranked $1^{\text {st }}$ at 5 sites in Khyber Pakhtunkhwa (KP) and $4^{\text {th }}$ across Pakistan. On $2^{\text {nd }}$ year mandatory evaluation in NUWYT, conducted during 2014-15, the genotype yield ranked $2^{\text {nd }}\left(4047 \mathrm{~kg} \mathrm{ha}^{-1}\right)$ at 31 sites on Pakistan basis. It is early maturing, disease tolerant and high yielding variety, more suitable for different agro-climatic zones of KP. Moreover, for yellow rust, leaf rust and stem rust, Relative Resistance Index (RRI) falls under acceptable range. The Provincial Seed Council (PSC), Khyber Pakhtunkhwa approved SRN-09111as a variety in $37^{\text {th }}$ meeting held on $19^{\text {th }}$ September, 2017 at Peshawar.

Keywords: Disease; High yield; Irrigated; KP; NIFA-AMAN 2017; Triticum aestivum; Variety

\section{Introduction}

Bread Wheat (Triticum aestivum L., $2 \mathrm{n}=6 \mathrm{x}=42$, BBAADD genome) is a worldwide cultivated food crop [1]. It is mostly adapted crop from irrigated to dry and from warm humid to dry cold environments.
The wheat genome is complex and diverse due to that the crop widely adapted [2].

Currently, a number of wheat cultivars are being grown by the farmers of Khyber Pakhtunkhwa. Although these varieties are playing a pivotal role in boosting the per acre 
yield but the frequent changes in disease virulence, in particular, yellow rust forced the breeders to develop new resistant varieties for productivity enhancement. Continuous development of agronomically superior wheat varieties with high grain yield, good nutrition value, processing quality and tolerance to biotic and abiotic stresses is crucial for ensuring food security [3-5]. Improving wheat may be more difficult than for many other crops, since the breeder needs to "match" quantity and quality, allying yield with grain and flour quality [6].

Wheat program at NIFA reflects to develop potential varieties for enhancing the productivity in general and particularly in Khyber Pakhtunkhwa (KP) province as wheat is the main staple food of Pakistan and important strategic agricultural commodity. The earlier wheat varieties, i.e., Bakhtawar92, Fakhre Sarhad and Bathoor-08 released for irrigated areas by this institute has played a pivotal role for increasing wheat production in the province. Overall, the country is selfsufficient at the moment but the scientists are in a continuous struggle to break the yield barriers being aware of the fact that in 2050 the 334.68 million populations will need about 37.14 million tons of wheat grain and the country must meet these requirements for its food security. Currently, wheat is being grown by $80 \%$ farmers (> 01 million) on about $40 \%$ of the total cultivated area and $65 \%$ of the food crops area in the country [7]. It contributes approximately $12.5 \%$ to the value added agriculture and $3.1 \%$ to GDP. The per capita wheat consumption in the country (125 kg a year) is among the highest in the world.

In Khyber Pakhtunkhwa wheat is grown on 0.738 million hectares and the production is
1.233 million tons as against the requirement of 3.0 million tons [7]. The current average yield of 1.56 tons per hectare in the province is very low. Due to high diseases and biophysical / socio-economic constraints the yield per acre is low. Therefore, continuous development and release of new high yielding / disease resistant varieties are direly needed to increase and stabilize wheat production in the province. The current manuscript discusses the development of new high yielding variety "NIFA AMAN-2017'. The botanical description and other characteristics of NIFA AMAN-2017 are below in (Table 1).

\section{Materials and Methods}

The genotype was received from CIMMYT in the $4^{\text {th }}$ Stem Rust Screening Nursery (SRSN) during 2009-10. The genotype at S. No. 6111 in the said nursery performed well regarding grain yield / rust resistance ( $\mathrm{Yr}$ and $L r$ ) and was selected for further studies for agronomic, disease resistance and yield performance. Initially, it was subjected to evaluation in regular yield trials in 2010-11 followed by multi-locational field evaluation for four consecutive crop seasons. The said genotype was designated with code name "SRN-09111". Randomized Complete Block Design (RCBD) was used for yield trials with the plot size of 04 rows ( $5 \mathrm{~m}$ long), keeping plant to plant and row to row spacing of 10 and $30 \mathrm{~cm}$, respectively. Data analyses were performed in Statistix 8.1. All the cultural practices were carried out according to the standard procedures as recommended for the crop under irrigated condition. The developmental history of NIFA AMAN-2017 is shown in (Table 2). 
Table 1. Botanical description and some characteristics of NIFA AMAN-2017

\begin{tabular}{|c|c|}
\hline Parentage & PRL/2*PASTOR//PBW343*2/KUKUNA/3/ROLF 07 \\
\hline Pedigree & CMSS04B00025T-0T0PY-0992TM-099Y-8WGY-0B \\
\hline Species & Triticum aestivum $(\mathrm{L})$ \\
\hline Origin & Exotic \\
\hline Breeding method & Introduction \\
\hline Areas of Adaptation & Irrigated areas of KP \\
\hline Days of maturity & Range [ $165-168$ ] \\
\hline Sowing Time & $1^{\text {st }}$ November to $25^{\text {th }}$ November \\
\hline Maturity Duration & Medium \\
\hline Suitable for Sowing & Early \\
\hline Seedlings growth habit & Semi erect \\
\hline Plant height $(\mathrm{cm})$ & Range [ $104-110$ ] \\
\hline Lodging & Absent \\
\hline Flag leaf attitude & Semi erect \\
\hline Ear emergence & [Days from Sowing] 119 \\
\hline Glume length size & Medium \\
\hline Beak size & Medium \\
\hline Seed color & Amber \\
\hline Seed size & Medium \\
\hline Protein $(\%)$ & 14.6 \\
\hline Chapati quality & Good \\
\hline Yield / acre (md) & 55 \\
\hline Stem rust (Black) & Resistance \\
\hline Leaf rust (Brown) & Resistance \\
\hline Stripe Rust (Yellow) & Resistance \\
\hline
\end{tabular}


Table 2 Summary of Developmental History of NIFA AMAN-2017 (SRN-09111)

\begin{tabular}{|c|c|c|c|}
\hline $\begin{array}{l}\text { S. } \\
\text { No. }\end{array}$ & $\begin{array}{l}\text { Crop } \\
\text { Year }\end{array}$ & Selection Source & Remarks/Activity \\
\hline 1 & 2009-10 & $\begin{array}{l}4^{\text {th }} \text { Stem Rust } \\
\text { Screening Nursery } \\
\text { (SRSN) }\end{array}$ & $\begin{array}{c}\text { Based on high grain yield and rust resistance to } Y r \text { and } L r \\
\text { the said entry at S. No. } 6111 \text { was initially selected and } \\
\text { designated as SRN-09111 (Table 3). }\end{array}$ \\
\hline 2 & 2010-11 & $\begin{array}{l}\text { Preliminary Yield } \\
\text { Trial-6 (Normal) }\end{array}$ & $\begin{array}{l}\text { SRN-09111 produced } 5000 \mathrm{~kg} \mathrm{ha}^{-1} \text { grain yield as against } \\
\text { the check cultivar Pirsabak-04 }\left(4167 \mathrm{~kg} \mathrm{ha}^{-1}\right)(\text { Table } 3) \text {. }\end{array}$ \\
\hline 3 & 2011-12 & $\begin{array}{l}\text { Advance Selection } \\
\text { Yield Trial-2 (Normal) }\end{array}$ & $\begin{array}{c}\text { Ranked } 2^{\text {nd }} \text { and out yielded both the check varieties } \\
\text { Bathoor-08 and Pirsabak-04 (Table 4). }\end{array}$ \\
\hline 4 & 2012-13 & Multi-location Trial & $\begin{array}{l}\text { Excelled the check variety Bathoor-08 after producing } \\
\left.\qquad 4210 \mathrm{~kg} \mathrm{ha}^{-1} \text { grain yield (Table } 5\right) .\end{array}$ \\
\hline 5 & 2013-14 & NUWYT $1^{\text {st }}$ Year & $\begin{array}{l}\text { Ranked } 1^{\text {st }} \text { at } 5 \text { sites in KPK and } 4^{\text {th }} \text { across Pakistan } \\
\text { (Table } 6 \& 7) \text {. }\end{array}$ \\
\hline 6 & 2014-15 & NUWYT $2^{\text {nd }}$ Year & Ranked $2^{\text {nd }}$ at 31 sites on Pakistan basis (Table 8 ). \\
\hline 7 & 2013-14 & Disease Screening & $\begin{array}{l}\text { Showed highly desirable RRI of } 8.79 \text { for } Y r \text { and } 8.68 \text { for } \\
\qquad \operatorname{Lr} \text { (Table 9). }\end{array}$ \\
\hline 8 & 2014-15 & Disease Screening & $\begin{array}{l}\text { Showed highly desirable RRI of } 8.85 \text { for } Y r ; 8.94 \text { for } L r \& \\
8.43 \text { for } S r \text { (Table } 10,11 \& 12 \text { ). }\end{array}$ \\
\hline 9 & 2013-14 & Quality Evaluation & $\begin{array}{l}\text { Meets the recommended quality standard with } 14.6 \\
\left.\text { percent protein for } 1^{\text {st }} \text { year (Table } 13\right) \text {. }\end{array}$ \\
\hline 10 & 2014-15 & Quality Evaluation & $\begin{array}{l}\text { Meets the recommended quality standard with } 15.55 \\
\text { percent protein } 2^{\text {nd }} \text { year (Table 14). }\end{array}$ \\
\hline
\end{tabular}

\section{Results and Discussion}

The grain yield results of SRN-09111(NIFA AMAN-2017) are shown in (Table 3 to 8). The results regarding mean grain yield in $4^{\text {th }}$ Stem Rust Screening Nursery (SRSN) sown during 2009-10 and Preliminary Yield Trial (PYT) conducted during 2010-11 at NIFA experimental farm depicted that SRN-09111 produced higher grain yields of 9867 and $5000 \mathrm{~kg} \mathrm{ha}^{-1}$ compared to check variety Bathoor-08 (9333 and $4167 \quad \mathrm{~kg} \mathrm{ha}^{-1}$, respectively (Table 3). In Advanced Yield Trials (AYTs), conducted during 2011-12, the candidate genotype (SRN-09111) produced high grain yields of $5023 \mathrm{~kg} \mathrm{ha}^{-1}$ against that of check varieties Bathoor- 08 (4747 kg ha-1) and Pirsabak-04 (4511 kg ha$\left.{ }^{1}\right)$ (Table 4). Similarly, in Micro-Plot Trials (MPT) conducted at five locations in irrigated areas of Khyber Pakhtunkhwa (Peshawar, Nowshera, Charsada, Swat and
Gilgit) during Rabi 2012-13, the genotype showed significantly higher mean grain yield of $4368 \mathrm{~kg} \mathrm{ha}^{-1}$ in comparison to mean grain yield of $3899 \mathrm{~kg} \mathrm{ha}^{-1}$ of check variety Bathoor-08 (Table 5). SRN-09111(NIFA AMAN-2017) also showed better results against the check varieties used for comparison in National Uniform Yield Trials (NUYTs) conducted by the National Wheat Coordinator, National Agricultural Research Centre (NARC), Islamabad, during 2013-14 and 2014-15. SRN-09111 ranked $1^{\text {st }}$ in NUWYT 2013-14, at 5 sites in KP and $4^{\text {th }}$ across Pakistan (Table $6 \&$ 7). As per the results of second mandatory evaluation in NUWYT (2014-15), the genotype ranked second at 31 sites across Pakistan (Table 8). The SRN-09111 produced mean grain yield of $5037 \mathrm{~kg} \mathrm{ha}^{-1}$ at 5 sites of Khyber Pakhtunkhwa in NUWYT 2013-14 which is higher compared to those of local check and 
Pirsabak-13 i.e. 4473 and $4751 \mathrm{~kg} \mathrm{ha}^{-1}$, respectively. However, the genotype (SRN09111) stood on $4^{\text {th }}$ position with mean grain yield of $3945 \mathrm{~kg} \mathrm{ha}^{-1}$ at 34 sites across the country compared to local check $\left(3877 \mathrm{~kg} \mathrm{ha}^{-}\right.$ $\left.{ }^{1}\right)$ and Pirsabak-2013 (3930 kg ha-1) in 201314 (Table 7). Similarly, with mean grain yield of $4047 \mathrm{~kg} \mathrm{ha}^{-1}, \mathrm{SRN}-09111$ got $2^{\text {nd }}$ position across the country compared to the local check (3973 kg ha $\left.{ }^{-1}\right)$, Pirsabak-2013 (3927 kg $\mathrm{ha}^{-1}$ ) and FSD-08 (3641 kg ha-1) during 201415 (Table 8). Global research endures in wheat breeding will continue to increase the yield potential in order to meet the food requirements of an ever increasing population [8].

Yellow rust of wheat is considered to be one of the most devastating diseases. It is not only limited to wheat but also infects barley, rye and more than 50 grass species [9]. It has the potential to cause $100 \%$ loss in wheat grain yield, if the susceptible cultivars become infected at an early stage and progress during the crop season. The damage by yellow rust is inflicted in the form of decreased yield, grain quality and forage value [10]. Furthermore, disease resistance in newly developed crop varieties controls yield losses [1], and a new crop variety should surpass the susceptible ones in terms of agronomic performance. Therefore, the genetically tolerant varieties cultivation is more useful and economical to prevent diseases in underdevelop countries [11, 12]. Beside Higher yielding capacity, the genotype under consideration was primarily selected on disease resistance basis. As reported by Crop Disease Research Institute (CDRI), Islamabad during 2013-14 and 2014-15, SRN-09111 (NIFA AMAN-2017) revealed desirable Relative Resistance Index (RRI) of $8.79 \& 8.85$ (acceptable: $>6$ ) for yellow rust $(Y r), 8.68 \& 8.94$ (acceptable: $>5$ ) for leaf rust $(\mathrm{Lr})$ and 8.43 for stem rust $(\mathrm{Sr})$ (Tables $9,10,11 \& 12)$.

Wheat is a key cereal crop for global economy and food security due to its protein and caloric values [13]. The chemical and physical quality characteristics of NIFA AMAN-2017 (SRN-09111) (high protein and gluten content in the grain) make it acceptable genotype for quality bread (Tables $13 \& 14)$. In order to ensure smooth and abundant supply of quality seed to the farmers [14], needed to evolve genetically improved wheat varieties with maximum seed production and for grain yield per unit area [14]. The current stagnancy in wheat yield can be overcome by introducing elite wheat germplasm. After testing the material under the local environment, either the promising genotypes can be used as improved varieties or they may be utilized in future breeding program for gene pyramiding in order to improve the agronomic traits of the existing varieties [15-17]. Moreover, with the passage of time, the recent varieties succumbed either due to adaptability problem [5] or new races of pathogen introduced [11]. Under such circumstances development of new improved verities with diseases tolerant, high yielding for commercial cultivation is imperative to fill up the gap created by exhausted varieties, avoid monoculture and stabilize wheat production. In light of the above mentioned realities, development and release of NIFA AMAN-2017 with inherent potential to higher yield, disease resistance, wider adaptability and good chapatti quality is a link to the chain of the word wide ongoing wheat breeding research efforts. It will not only meet the ultimate desire of the farmers for higher grain yield but will significantly add to bridging the yield gap in wheat production in the province as well as in the country. 
Table 3. Yield performance of SRN-09111 in $4^{\text {th }}$ SRSN (2009-10) and Preliminary Yield Trial (PYT) 2010-11at NIFA

\begin{tabular}{|c|c|c|c|c|}
\hline \multirow{2}{*}{ Year } & \multirow{2}{*}{ Trial / Nursery } & \multicolumn{2}{|c|}{ Grain Yield (kg ha-1) } & \multirow{2}{*}{ \% \pm over Check } \\
\cline { 3 - 4 } $2009-10$ & $\begin{array}{c}4^{\text {th }} \text { SRSN } \\
\text { (Entry \# 6111) }\end{array}$ & 9867 & 9333 & +5.72 \\
\hline $2010-11$ & $\begin{array}{c}\text { PYT-6 -Normal } \\
\text { (Entry \# 117) }\end{array}$ & 5000 & 4167 & +20.0 \\
\hline
\end{tabular}

Table 4. Yield performance of SRN-09111 in Advanced Selections Yield Trials (ASYT) at NIFA, 2011-12

\begin{tabular}{|c|c|c|c|}
\hline \multirow{2}{*}{ Trial } & \multicolumn{2}{|c|}{ Grain Yield $\left(\mathrm{kg} \mathrm{ha}^{-1}\right)$} & \multirow{2}{*}{$\% \pm$ over Check } \\
\hline & SRN-09111 & Check (Bathoor-08) & \\
\hline $\begin{array}{l}\text { ASYT-2, Normal } \\
\text { (Entry \# 30) }\end{array}$ & 5556 & $\begin{array}{l}5111 \text { (Bathoor-08) } \\
5422 \text { (Pirsabak-04) }\end{array}$ & $2.47-8.70$ \\
\hline $\begin{array}{l}\text { ASYT-2, Late } \\
\text { (Entry \# 30) }\end{array}$ & 4489 & $\begin{array}{l}4383 \text { (Bathoor-08) } \\
3600 \text { (Pirsabak-04) }\end{array}$ & $2.41-24.70$ \\
\hline Mean values & 5023 & $\begin{array}{l}4747 \text { (Bathoor-08) } \\
4511 \text { (Pirsabak-04) }\end{array}$ & $5.81-11.35$ \\
\hline
\end{tabular}

Table 5. Mean yield performance of SRN-09111 in Micro-Plot Trials at 5 locations in irrigated areas of Khyber Pakhtunkhwa, 2012-13

\begin{tabular}{|c|c|c|c|}
\hline \multirow{2}{*}{ Locations } & \multicolumn{2}{|c|}{ Grain Yield (kg ha-1) } & \multirow{2}{*}{$\begin{array}{c}\% \pm \text { over } \\
\text { Check }\end{array}$} \\
\hline & SRN-09111 (Entry \# 12) & Check (Bathoor-08) & \\
\hline NIFA, Peshawar & 4333 & 3134 & 38.0 \\
\hline Pirsabak, Nowshera & 3268 & 3145 & 4.0 \\
\hline Farmer's Field Charsadda & 4889 & 3663 & 33.0 \\
\hline Swat & 4073 & 4332 & -6.0 \\
\hline Gilgit & 5278 & 5222 & 1.0 \\
\hline Mean values & 4368 & 3899 & 12.0 \\
\hline
\end{tabular}

Table 6. Mean yield performance of SRN-09111 in NUWYT (Normal \& Late) planted in different irrigated zones of Khyber Pakhtunkhwa (KPK), 2013-14

\begin{tabular}{|c|c|c|c|c|}
\hline \multirow{2}{*}{ Entry } & \multicolumn{3}{|c|}{ Grain Yield (kg ha-1) 5 sites } & \multirow{2}{*}{$\begin{array}{c}\text { Ranking on KPK } \\
\text { basis }\end{array}$} \\
\cline { 2 - 4 } & Normal & Late & Average & \multirow{2}{*}{$1^{\text {st }}$} \\
\hline SRN-09111 & 5647 & 4426 & 5037 & \\
\hline Local Check & 5040 & 3907 & 44473 & \\
\hline Pirsabak-2013 & 5419 & 4082 & 4751 & \\
\hline$\% \pm$ over Checks & $4.2-12.0$ & $8.4-13.2$ & $6.0-12.6$ & \\
\hline
\end{tabular}


Table 7. Mean yield performance of SRN-09111 in NUWYT (Normal \& Late) at 34 locations across Pakistan, 2013-14

\begin{tabular}{|c|c|c|c|c|}
\hline \multirow{2}{*}{ Entry } & \multicolumn{2}{|c|}{ Grain Yield (kg ha-1) 34 sites } & \multirow{2}{*}{$\begin{array}{c}\text { Ranking on } \\
\text { Pakistan basis }\end{array}$} \\
\cline { 2 - 4 } & Normal & Late & Average & \multirow{2}{*}{$4^{\text {th }}$} \\
\hline SRN-09111 & 4351 & 3538 & 3945 & \multirow{2}{*}{} \\
\hline Local Check & 4285 & 3470 & 3877 & \\
\hline Pirsabak-2013 & 4370 & 3491 & 3930 & \\
\hline
\end{tabular}

Table 8. Mean yield performance of SRN-09111 in NUWYT planted at different irrigated zones across Pakistan, 2014-15

\begin{tabular}{|c|c|c|c|c|c|}
\hline S. \# & Entry & KPK (6) & Sind (4) & Punjab (21) & Pakistan (31) $^{\text {(3) }}$ \\
\hline 6 & SRN-09111 & 3960 & 3894 & $\mathbf{4 1 0 1 ~ 1 ~}^{\text {st }}$ & $\mathbf{4 0 4 7 ~ 2 ~}^{\text {nd }}$ \\
\hline 38 & Local Check & 4150 & 4037 & 3910 & 3973 \\
\hline 39 & FSD-08 & 3702 & 3947 & 3566 & 3641 \\
\hline 40 & PAK-2013 & 3863 & 4308 & 3872 & 3927 \\
\hline
\end{tabular}

Table 9. Terminal disease reaction, resistant indices and cooperative data of NUWYT irrigated, 2013-14

\begin{tabular}{|c|c|c|c|c|c|c|c|}
\hline \multirow{2}{*}{ S. \# } & \multirow{2}{*}{ Entry } & \multicolumn{3}{|c|}{$\boldsymbol{Y r}$} & \multicolumn{2}{c|}{$\boldsymbol{L r}$} & $\boldsymbol{S r}$ \\
\cline { 3 - 7 } & & TR & ACI & RRI & ACI & RRI & TR \\
\hline 07 & SRN-09111 & 5 MRMS & 1.6 & 8.79 & 1.2 & 8.68 & $40 \mathrm{MR}$ \\
\hline
\end{tabular}

Table 10. Response of SRN-09111 to yellow rust along with their Average Coefficient Infection, Country Average Relative Percent Attack and Relative Resistance Index, 2014-15

\begin{tabular}{|c|c|c|c|c|c|c|c|}
\hline S. \# & Entry & Islamabad & Peshawar & Nowshera & ACIs & CARPA & RRI \\
\hline 06 & SRN-09111 & 5MR & 0 & 0 & 0.67 & 1.72 & 8.85 \\
\hline
\end{tabular}

Table 11. Response of Candidate lines to leaf rust along with their Average Coefficient Infection, Country Average Relative Percent Attack and Relative Resistance Index, 2014-15

\begin{tabular}{|c|c|c|c|c|c|c|c|c|c|c|c|}
\hline $\begin{array}{c}\text { S. } \\
\#\end{array}$ & Entry & Karachi & T. jam & Thatta & Kunri & Thatta & Faisalabad & BWP & ACIs & CARPA & RRI \\
\hline 1 & 99172 & TMS & TMSS & TMS & TMSS & TMSS & 5 MSS & $\begin{array}{c}10 M \\
\text { SS }\end{array}$ & 2.79 & 11.70 & 7.95 \\
\hline 2 & 99346 & TMS & TMSS & TMSS & $\begin{array}{c}10 \text { MS } \\
\text { S }\end{array}$ & TMSS & 10 MSS & $\begin{array}{c}10 M \\
\text { SS }\end{array}$ & 4.38 & 14.98 & 7.65 \\
\hline 3 & 112802 & $50 M S S$ & $30 M S S$ & 5 MSS & 5 MSS & 5 MSS & 30 MSS & $\begin{array}{c}20 M \\
\text { SS }\end{array}$ & 17.44 & 60.69 & 0.39 \\
\hline 4 & DN-102 & 5 MSS & $10 M S S$ & TMSS & 5 MSS & 5 MSS & 0 & 0 & 3.04 & 10.40 & 8.06 \\
\hline 5 & CT-09137 & TMSS & $10 M S S$ & TMSS & TMSS & TMSS & 0 & $\begin{array}{c}5 \text { MS } \\
\text { S }\end{array}$ & 2.7 & 9.23 & 8.17 \\
\hline $\mathbf{6}$ & SRN09111 & TMS & $\mathbf{0}$ & $\mathbf{0}$ & $\mathbf{0}$ & $\mathbf{0}$ & $\mathbf{0}$ & $\mathbf{0}$ & $\mathbf{0 . 2 1}$ & $\mathbf{0 . 7 2}$ & $\mathbf{8 . 9 4}$ \\
\hline
\end{tabular}


Table 12. Response of Candidate lines to stem rust along with their Coefficient Infection, Country Average Relative Percent Attack and Relative Resistance Index, 2014-15

\begin{tabular}{|c|c|c|c|c|c|}
\hline S. \# & Entry & Stem Rust & CI & CARPA & RRI \\
\hline 1 & 99172 & $40 \mathrm{MR}$ & 16 & 25.44 & 6.71 \\
\hline 2 & 99346 & $70 \mathrm{M}$ & 42 & 66.78 & 2.98 \\
\hline 3 & 112802 & $50 \mathrm{MS}$ & 40 & 63.6 & 3.276 \\
\hline 4 & DN-102 & $60 \mathrm{M}$ & 36 & 57.24 & 3.84 \\
\hline 5 & CT-09137 & $60 \mathrm{M}$ & 36 & 57.24 & 3.84 \\
\hline 6 & SRN-09111 & $\mathbf{1 0 M R}$ & $\mathbf{4}$ & $\mathbf{6 . 3 6}$ & $\mathbf{8 . 4 3}$ \\
\hline
\end{tabular}

Table 13. Quality evaluation of National Uniform Wheat Yield Trials (irrigated) for SRN-09111, 2013-14

\begin{tabular}{|c|c|c|c|c|c|c|c|c|}
\hline S. \# & Entry & $\begin{array}{c}\mathbf{1 0 0 0} \\
\text { K. wt } \\
(\mathbf{g})\end{array}$ & $\begin{array}{c}\text { Test wt. } \\
\left(\mathbf{k g ~ h a}^{-1}\right)\end{array}$ & $\begin{array}{c}\text { Starch } \\
\mathbf{\%}\end{array}$ & $\begin{array}{c}\text { Moist. } \\
\mathbf{\%}\end{array}$ & $\begin{array}{c}\text { Grain protein } \\
(\boldsymbol{\%} \text { d.b) }\end{array}$ & $\begin{array}{c}\text { Gluten } \\
\text { dry (\%) }\end{array}$ & $\begin{array}{c}\text { Gluten } \\
\text { wet (\%) }\end{array}$ \\
\hline 7 & SRN-09111 & 36.1 & 71.9 & 52.3 & 11.7 & 14.6 & 8.9 & 27.1 \\
\hline
\end{tabular}

Table 14. Quality evaluation of National Uniform Wheat Yield Trials (irrigated) for SRN-09111, 2014-15

\begin{tabular}{|c|c|c|c|c|c|c|}
\hline S. \# & Entry & $\begin{array}{c}\mathbf{1 0 0 0} \\
\text { K. wt } \mathbf{( g )}\end{array}$ & $\begin{array}{c}\text { Test.wt } \\
\left(\mathbf{k g ~ h a}^{-\mathbf{1}}\right)\end{array}$ & $\begin{array}{c}\text { Protein } \\
(\boldsymbol{\%})\end{array}$ & $\begin{array}{c}\text { Starch } \\
(\boldsymbol{\%})\end{array}$ & $\begin{array}{c}\text { Gluten } \\
(\boldsymbol{\%})\end{array}$ \\
\hline 6 & SRN-09111 & 36.7 & 76.65 & 15.55 & 52.65 & 35.5 \\
\hline
\end{tabular}

\section{Conclusion}

NIFA AMAN-2017 is a disease tolerant and high yielding wheat variety and mainly recommended for cultivation in KP irrigated areas. It has an edge in grain yield over the check varieties at NIFA and other location of $\mathrm{KP}$ and Pakistan. The plant type is semi dwarf, in irrigated areas responsive to high input and also recommended for cultivation in diverse environment of the province.

\section{Authors' contributions}

Conceived and designed the experiments: F Subhan, Performed the experiments: F Subhan \& MI Khan, Analyzed the data: F Subhan, M I Khan \& ST Shah, Contributed materials/ analysis/ tools: F Subhan, MI Khan \& ST Shah, Wrote the paper: ST Shah \& F Subhan.

\section{References}

1. Rahmatov M, Otambekova M, Muminjanov H, Rouse MN, Hovmøller
MS, Nazari K, Steffenson BJ \& Johansson E (2019). Characterization of stem, stripe and leaf rust resistance in Tajik bread wheat accessions. Euphytica 215: 55.

2. Shiferaw B, Smale M, Braun HJ, Duveiller E, Reynolds M \& Muricho G (2013). Crops that feed the world 10. Past successes and future challenges to the role played by wheat in global food security. Food Secur 5:291-317.

3. Mondala S, Singha RP, Masonb ER, Huerta-Espinoa J, Autriquea E \& Joshi AK (2016). Grain yield, adaptation and progress in breeding for early-maturing and heat-tolerant wheat lines in South Asia. Field Cro Res 192:78-85.

4. Khan, MI, Mohammad T, Subhan F, Amin M \& Shah ST (2007). Agronomic evaluation of different bread wheat (Triticum aestivum L) genotypes for 
terminal heat stress. Pak J Bot 39(7): 2415-2425.

5. Subhan F, Nazir A, Anwar M, Nazir HS, Siddiq M, Rahman J \& Sajad T (2004). Response of newly developed wheat cultivars/advance lines to planting dates in the central agro-ecological zone of NWFP. Asian J Plant Sci 3(1): 87-90.

6. Shewry PR (2009). Wheat. J Exp Bot 60:1537-53

https://doi.org/10.1093/jxb/erp058.

7. Ministry of National Food Security and Research, Islamabad (2018). Agricultural Statistics of Pakistan (2017-18).

8. Borlaug NE (2007). Sixty-two years of fighting hunger: personal recollections. Euphytica 157: 287-297.

9. Line RF (2002). Stripe rust of wheat and barley in North America: A retrospective historical review. Rev Phytopathol 40: 75-118.

10. Waqar A, Khattak SH, Begum S, Rehman T, Rabia, Shehzad A, Ajmal W, Zia SS, Siddiqi I \& Ali GM (2018). Stripe rust: A review of the disease, $\mathrm{Yr}$ genes and its molecular markers. Sarhad J of Agric 34(1): 188-201.

11. Khan IM, Ajab M, Khattak GSS, Mohammad T \& Shah JA (2009). Genetic behavior of controlling area under disease progress curve for stripe rust $(P$. striiformis f. sp. Tritici) in two wheats ( $T$. aestivum L.) crosses. Phytopathol 99 (11): 1265-1272.
12. Ellis JG, Lagudah ES, Spielmeyer W, Dodds PN (2014). The past, present and future of breeding rust resistant wheat. Front Plant Sci 5: 641.

13. Venske E, Santos RS, Busanello C, Gustafson P\& Oliveira AC (2019). Bread wheat: a role model for plant domestication and breeding. Hereditas 156: 16.

14. Hashim, MK, Nasir-ud-Din, Khakwani AA, Baloch MS, Zubair M, Saifullah Khan \& Khan AW (2011). Hashim-8: a Short Duration, High Yielding and Disease Resistant Wheat Variety for Rain-fed Areas of Pakistan. Int J Agric Biol 13(6): 956-960.

15. Zulfiqar F \& Hussain A (2014). Forecasting wheat production gaps to assess the future food security in Pakistan. $J$ Food Nutr Disor 3(3): http://dx.doi.org/10.4172/23249323.1000146 .

16. Joshi KD, Rehman AU, Ullah G, Nazir MF, Zahara M, Akhtar J, Khan M, Baloch A, Elahi E, Khan A, Suleman M \& Imtiaz M (2017). Acceptance and competitiveness new improved wheat varieties smallholder farmers. J of Crop Improv 31(4): 608-627.

17. Khattak GSS, Saeed I \& Ibrar M (2019). New high yielding and disease resistant mungbean [Vigna radiata (L.) Wilczek] variety "NIFA Mung-19”. Pure Appl Biol 8(2):1444-1455. 